\title{
De 'governmentality' van een lokaal prostitutieveld?
}

werk in uitvoering

\author{
Author(s) \\ van Wijk, Eelco \\ DOl \\ 10.5553/RdW/138064242017038001005
}

\section{Publication date}

\section{7}

\section{Document Version}

Final published version

Published in

Recht der Werkelijkheid

Link to publication

\section{Citation for published version (APA):}

van Wijk, E. (2017). De 'governmentality' van een lokaal prostitutieveld? werk in uitvoering. Recht der Werkelijkheid, 38(1), 7377. https://doi.org/10.5553/RdW/138064242017038001005

It is not permitted to download or to forward/distribute the text or part of it without the consent of the author(s) and/or copyright holder(s), other than for strictly personal, individual use, unless the work is under an open content license (like Creative Commons).

If you believe that digital publication of certain material infringes any of your rights or (privacy) interests,

please let the Library know, stating your reasons. In case of a legitimate complaint, the Library will make the material inaccessible and/or remove it from the website. Please contact the library:

https://www.amsterdamuas.com/library/contact/questions, or send a letter to: University Library (Library of the University of Amsterdam and Amsterdam University of Applied Sciences), Secretariat, Singel 425, 1012 WP Amsterdam, The Netherlands. You will be contacted as soon as possible. 


\title{
De 'governmentality' van een lokaal prostitutieveld?
}

\author{
Eelco van Wijk
}

De legalisering van prostitutie 2000 was een poging van de overheid om in te grijpen in de logica van een relatief autonoom opererende prostitutiesector. Door het legaliseren werd de markt voor het verkopen van seksuele diensten niet langer als moreel verwerpelijk, maar (impliciet) als acceptabel bestempeld. Via het ontwerpen van regulering en sturing, een taak grotendeels gedecentraliseerd naar gemeenten, moest vervolgens de interactie tussen sekswerkers, klanten en exploitanten worden veranderd. Prostitutie werd daarmee primair een zaak van besturen.

$\mathrm{Nu}$, bijna twee decennia later, heeft de discussie rondom prostitutie (beleid) echter nog steeds een moreel karakter. Ik betoog dat de wijze waarop prostitutie (niet alleen in Nederland) wordt bestudeerd als onderwerp van wetenschap onder andere op dat punt tekortschiet. Ten eerste is er een te grote focus op (veranderingen in) nationaal beleid en te weinig op wat cruciale actoren (zoals gemeenten) daadwerkelijk binnen lokale prostitutiesectoren doen. Ten tweede, áls er aandacht wordt besteed aan lokale actoren, is er onvoldoende aandacht voor de invloed van morele aspecten. Mijn promotieonderzoek poogt aan deze twee tekortkomingen tegemoet te komen, door te kijken naar de relatie tussen morele opvattingen rondom prostitutie en de wijze waarop actoren op lokaal niveau pogen de prostitutiemarkt naar hun hand te zetten.

Door meerdere auteurs werd de legalisering van prostitutie in eerste instantie opgevat als een stap van moreel conflict naar morele eenheid. Zo schrijft Boutellier (1993) dat de prostituee niet langer werd gezien als slachtoffer en dat daarmee de morele grondslag om prostitutie te verwerpen was vervallen. Het beroep zelf stond niet meer ter discussie. Een vergelijkbaar geluid treffen we aan bij Outshoorn (2004), bij wie deze constatering uitdrukkelijk een normatieve positieve evaluatie van deze ontwikkeling ademt. In plaats van moreel gedreven beleid zou er sprake zijn van typisch Nederlands pragmatisch beleid: prostitutie zou vanaf nu een geaccepteerd fenomeen zijn.

Hoe anders is het nu? Volgens diezelfde Outshoorn (2012, 2014) is er sprake van de terugkeer van het verdwenen veronderstelde slachtofferschap. Nu niet zozeer als slachtoffer van de seksuele daad an sich, maar als slachtoffer van mensenhandel, uitbuiting of economische omstandigheden. Het ooit als amoreel en pragmatisch geduide beleid wordt via een nieuwe weg wederom 'gemoraliseerd'.

Bovenstaande auteurs laten echter twee belangrijke empirische vragen onbeantwoord. Ten eerste gaat achter beide analyses het idee schuil dat er sprake is van morele eenvormigheid; dat er zelfs in een zo'n moreel betwist terrein als prostitu- 
tie gesproken kon of kan worden over een enkele dominante morele opvatting. Maar is dat wel terecht? Onderkent de constatering dat het debat wederom eenzijdig gemoraliseerd wordt wel voldoende de veelheid aan morele opvattingen die aanwezig waren en zijn, en gehanteerd worden?

Ten tweede laten bovenstaande analyses de vraag liggen wat er nu daadwerkelijk gebeurt op lokaal niveau, waar het gros van de wetgevende en handhavingstaken aan gemeenten is uitbesteed. Agustín (2005; 2008) onderschrijft het belang van dit niveau. Zij betoogt dat een primair nationale focus de eigen verhalen en drijfveren van hen die zich daadwerkelijk in de sector als actoren begeven negeert. De werking van een prostitutiesector verklaren aan de hand van nationaal beleid, zonder aandacht te besteden aan de specifieke dynamiek van de lokale uitwerking daarvan, is volgens Agustín (ibid.) dan ook een relatief zinloze exercitie. Zij pleit daarom voor een 'cultural study of commercial sex', ${ }^{1}$ waarin de wijze waarop actoren zich bewegen op prostitutiemarkten centraal staat. Bestuur wordt daarmee de resultante van een samenspel van verschillende actoren en kan derhalve als gefragmenteerd worden beschouwd.

Uitgaan van het idee van gefragmenteerd bestuur versterkt de noodzakelijkheid van het onderzoeken van heterogene morele opvattingen van de verschillende lokale actoren. Als er steeds meer (institutionele) actoren in de analyse betrokken raken, elk met hun eigen opvattingen en drijfveren, wie of wat 'produceert' dan nog een dominante richtinggevende morele opvatting? Of is er geen sprake van één dominante opvatting? Kortom, een gefragmenteerde opvatting van de productie van bestuur moet per definitie gepaard gaan met een gefragmenteerde opvatting van de productie van moraliteit. Dat schept ruimte voor vragen rondom de invloed van diverse morele opvattingen binnen lokale prostitutiesectoren.

Mijn promotieonderzoek poogt precies deze vragen te beantwoorden. Onder de brede vraag Who governs prostitution, how, and why? doe ik onderzoek naar een lokale prostitutiesector. Hanteren actoren verschillende morele opvattingen ten aanzien van prostitutie? Hoe beïnvloeden deze het handelen en sturen? Pogen en slagen actoren erin om hun morele opvattingen aan andere actoren op te dringen en zo de sturing van de sector naar hun hand te zetten?

\section{Een conceptueel instrumentarium voor de gefragmenteerde productie van bestuur en moraal?}

Het vorenstaande vraagt om een conceptueel en theoretisch instrumentarium dat om kan gaan met een gefragmenteerde opvatting van bestuur enerzijds en de rol daarbinnen van (mogelijk) diverse morele opvattingen en attitudes anderzijds. De relevantie van een dergelijk instrumentarium neemt in brede zin toe. Voor auteurs als Bauman (1995) onderscheidt de laat- of postmoderne samenleving zich van de moderne orde door fragmentatie. De centraliserende krachten uit de moderniteit komen onder druk komen te staan door maatschappelijke ontwikkelingen zoals individualisering, technologisering en globalisering. Dat heeft tot 
gevolg dat niet alleen bestuur zich fragmenteert (glokaliseert, ${ }^{2}$ decentraliseert). Ook vragen rondom moraliteit, welke volgens zowel Bauman (1995) als Giddens in de moderniteit werden gekoloniseerd door 'modernity's drive to achieve control, ${ }^{3}$ keren in de laatmoderne tijd noodzakelijkerwijs terug. ${ }^{4}$ Door het afkalven van traditionele instituties worden individuen in toenemende mate gedwongen om zelf antwoorden te formuleren op morele vragen die hun handelen richting geven. De gevolgen van deze ontwikkelingen karakteriseer ik als de laatmoderne dubbele fragmentatie van 'de productie van bestuur' (welke actoren sturen?) en de 'productie van moraliteit' (wat is 'het goede' dat actoren willen nastreven).

In dit onderzoek poog ik de beide fragmentaties serieus te nemen door inzichten uit veldtheorieën ${ }^{5}$ te combineren met foucaultiaanse governmentality-ideeën. Dat doe ik door een lokale prostitutiesector te bestuderen als een strategisch veld ${ }^{6}$ of als dispositif. ${ }^{7}$ Binnen strategische velden wordt het bestuur van een veld opgevat als de resultante van de interactie tussen verschillende binnen het veld opererende actoren (gefragmenteerd bestuur). Actoren 'strijden' of 'spelen' om hun positie in het veld te verbeteren of te bestendigen en de status quo van het veld als geheel te behouden of doorbreken. De stabiliteit van een veld rust op de mate waarin er sprake is van shared understanding. ${ }^{8}$ Shared understanding bestaat uit vier componenten:

1 overeenstemming over wat er voor het veld als geheel op het spel staat en wat het nut van het veld is;

2 overeenstemming over welke 'set' actoren deelneemt en hoe die zich tot elkaar verhouden in termen van machtsrelaties;

3 overeenstemming over wat de 'spelregels' van het spel van het veld zijn; en

4 de frames die de individuele en collectieve actoren hanteren om het handelen van anderen te begrijpen.

Het zijn deze vier aspecten en de mate waarin ze al dan niet gedeeld worden, waar de gefragmenteerde productie van moraliteit is te lokaliseren. Een dergelijke veldanalyse roept vragen op als: 'Onder welke voorwaarden zouden seksuele diensten verkocht moeten worden?' 'Op welke spelers stemmen actoren hun handelen af?' 'Is er overeenstemming over hoe prostituees, exploitanten en klanten zich tot elkaar moeten verhouden?'

Deze strategische veldenbenadering is echter zeer breed en belicht onvoldoende de specifieke karakteristieken van een politieke beleids- en bestuurscontext. En

2 Glokalisering is de gelijktijdige beweging van lokalisering en globalisering.

3 Smith 2002, p. 44.

4 Zie Smith (2002) voor een uitleg en kritische bespreking van het idee dat reflexieve moraliteit in de laatmoderne samenleving haar herintrede doet.

5 Fligstein \& McAdam 2012.

6 Fligstein \& McAdam 2012.

7 Foucault 1980.

8 Fligstein \& McAdam 2012. 
het is daar waar een governmentality-benadering concretere invulling biedt. ${ }^{9}$ Ten eerste omdat deze de op prostitutie gerichte moraliteit expliciet verbindt met de politieke moraliteit over hoe te besturen (bijv. liberalisme of welfarism). Ten tweede omdat het de daarmee verbonden technieken en strategieën (arts of government) aan de oppervlakte brengt. Dan worden vragen noodzakelijk als: 'Welke mentaliteiten en rationaliteiten hanteren actoren?' 'Welke middelen, procedures en interventies zetten zij in?' En: 'Welke actoren slagen erin om hun mentaliteiten aan anderen en het veld als geheel op te leggen?' 'Ontstaat er uit die interacties zoiets als de governmentality van een lokale prostitutiesector?'

\section{Het empirische onderzoek}

Het onderzoek krijgt zijn empirische vorm in een enkelvoudige in-depth casestudy, in de gemeente Den Haag. Aan de hand van semigestructureerde interviews met relevante actoren (prostituees, klanten, exploitanten, gemeente, politie, welzijnswerkers) zijn de morele opvattingen van (groepen) van actoren en de sturingsmechanismen die zij hanteren boven water gehaald. Ook zijn vergaderingen van brancheverenigingen, raadsvergaderingen en symposia over prostitutie waar gemeenten en experts bijeenkomen bezocht en beleidsdocumenten geanalyseerd. Het resultaat wordt een proefschrift, dat niet alleen in beeld brengt door wie, op welke wijze en met welke achterliggende morele opvattingen prostitutie wordt bestuurd. Het poogt eveneens door de ontwikkeling en toepassing van een theoretisch instrumentarium waarin de gefragmenteerde productie van bestuur en moraliteit centraal staan recht te doen aan de vragen en problemen die de laatmoderne maatschappelijke conditie de wetenschap en bestuurders voor de voeten werpt.

\section{Referenties}

Agustín, L., 'The Cultural Study of Commercial Sex', Sexualities, 2005, 8, p. 681-694.

Agustín, L., 'Sex and the limits of enlightenment: The irrationality of legal regimes to control prostitution', Sexual Research and Social Policy 2008, 5, p. 73-86.

Bauman, Z., Life in Fragments. Essays in Postmodern Morality, Oxford: Blackwell Publishing 1995.

Boutellier, H., Solidariteit en slachtofferschap, SUN: Nijmegen 1993.

Dean, M., Governmentality. Power and rule in modern society, Londen: SAGE 2010.

Fligstein, N. \& D. McAdams, A Theory of Fields, Oxford: Oxford University Press 2012.

Foucault, M., 'The confessions of the flesh', in: C. Gordon (Ed.), Power/knowledge: selected interviews and other writings 1972-1977. New York: Vintage Books 1980, p. 194-228.

Outshoorn, J., 'Pragmatism in the Polder: Changing Prostitution Policy in The Netherlands', Journal of Contemporary European Studies, 2004, 12

9 Governmentality kan worden omschreven als de verbinding tussen 'government' als activiteit (het vormgeven van (de context van) het handelen van anderen), en hoe deze activiteit is verbonden met hoe we denken over deze activiteit; de rationaliteit of mentaliteit die schuilgaat achter de activiteit (Dean 2010). 
Outshoorn, J., 'Policy Change in Prostitution in the Netherlands: from Legalization to Strict Control', Sexuality Research and Social Policy, 2012, 9.

Smith, C., "The Sequestration of Experience: Rights Talk and Moral Thinking in "Late Modernity"', Sociology, 2002, 12, p. 43-66. 